\title{
Financing innovative start-ups in Portuguese context: what is the role of business angels networks?
}

\author{
José Bilau ${ }^{1} \cdot$ Soumodip Sarkar ${ }^{2}$ \\ Received: 28 February 2015 / Accepted: 17 September 2015 / \\ Published online: 1 October 2015 \\ (C) Springer Science+Business Media New York 2015
}

\begin{abstract}
Business angels provide both financing and managerial experience, which increase the likelihood of the survival of innovative start-ups. Over the last years, European countries with developing informal venture capital markets have seen governments support the creation of business angels networks (BANs) to increase and consolidate these markets. Using the Portuguese context to carry out the empirical work, this paper provides an assessment of value added provided by angels' networks. A total of 88 useable responses were received and analysed using non-parametric statistical techniques. This paper demonstrates that is evidence of positive contribution of BANs in terms of bringing together investors and linking them with entrepreneur's seeking finance. BANs played an important role in financing innovative start-ups also in peripheral regions. Results lead us to conclude that government support BANs would appear to be an effective mechanism to stimulate the angel market in developing informal venture capital markets. The conclusions of this paper are likely to have relevance for countries where there is growing interest in the potential of business angels as a means of financing innovative start-ups.
\end{abstract}

Keywords Innovative start-ups · Business angels · Business angel's networks · Government policy

\section{Introduction}

While innovation is regarded as the key to economic growth and regional development, entrepreneurs increasingly need to seek at alternatives to bank funding for their

José Bilau

jose.bilau@ipbeja.pt

1 Polytechnic Institute of Beja/ESTIG, Beja, Portugal, R. Pedro Soares, Campus do IPB, 7800-295 Beja, Portugal

2 Department of Management \& CEFAGE-UE, Universidade de Évora, University of Évora/Évora, Portugal, Largo Marques de Marialva, Palácio do Vimioso, Évora 7002-554, Portugal 
financing needs. These alternative sources have become especially critical in times of financial crises, more so in Europe. Unfortunately, both extant research on entrepreneurship and innovation, as well as policymakers, tend to give less attention to these outside equity mechanisms than their importance deserves. In this context, following family and friends, angel investment has now become the largest source of outside equity financing at the start-up and early growth stages (Sohl 2007; 2012). Understanding the role of business angels and the BA networks, to which they belong, therefore, becomes crucial given the significant contribution in stimulating entrepreneurial activity and consequently economic growth.

Business angels, who are themselves often experienced entrepreneurs or business people, have become increasingly recognised as an important source of equity capital to innovative start-ups. In addition to the capital provided, business angels play a key role in providing strategic and operational expertise for new ventures as well as social capital (OECD 2011). Furthermore, business angels are geographically widespread, which means that their investments contribute to financing also in peripheral regions. Data collected by the European Business Angel Network (EBAN) show that firms in the ICT, biotech and healthcare energy/environment and mobile technologies attract the most investments from business angels. However, in many countries, the business angel market is still nascent and barely visible. EU countries with developing informal venture capital markets have seen governments support business angels networks (BANs) to increase and consolidate business angels markets in order to make available financing to innovative start-ups. BANs can play a very important role in countries with a developing business angel market. When the BA market is far from being organized, the part played by BANs is extremely important to understand the functioning of the angel market and in publicizing existing groups of BAs to current and potential BAs. Angel networks also play a recognized role in addressing the information asymmetry problem caused by the high search cost for entrepreneurs and angels as they try to find one another (Mason and Harrison 1999; 2002; Mason 2009; Wetzel 1987). BANs can also take on the role of facilitating co-investment between BAs, as well as promoting BA contact with formal risk capital.

There has been an increasing number of studies that have linked growth from higher innovation rates in industries and regions that have been able to attract greater venture capital and private investment such as those from BAs (Kortum and Lerner 2000; Popov and Roosenboom 2012). When start-ups and other innovative companies establish in a region, patenting rates tend to increase (Samila and Sorenson 2011), as well as having an impact or regional growth via increased employment and economic activity. Thus, having active regional BANs can be a stimulating factor in regional growth.

Angel networks provide a platform for the sharing of practices (conferences, workshops, etc.), thus contributing to the visibility of BA investment. Besides, BANs provide representation to BAs in meetings with policymakers to discuss juridical regimes, fiscal legislation and identification and removal of barriers to BA market development in these countries. They also form links with transnational organizations to develop cooperative activities such as developing professional standards. The usefulness of BANs is also shown in collecting data from member organizations in the "visible" angel market within the country (EBAN 2008a). In some countries, these organizations are also involved in training and mentoring programmes for angel investors. 
Given the importance of the activities carried out by angel networks, all of which are mostly not-for profit entities, the support given to these organizations by government bodies is understandable in contexts where the BA market is still developing, as is the case of continental Europe where EBAN, the pan-European association for the industry, was created only in 1999 with European Commission support. Many of the BAN federations and BANs across Europe were also created and helped in the early years of operation with national support (European Commission 2003; EBAN 2008b; OECD 2011) starting the beginning of this century. Besides the general financing allocated to creating and operating associations, federations and angel networks in Europe, we also find examples of some government financing to support specific activities (e.g. support for LINC Scotland to promote new business angel syndicates or government support in Spain to provide certification for BAs).

Given their importance in stimulating innovative start-ups, one would expect to find in the literature significant research on the impact of the role of BANs. However, extant research on the role of BANs reveals mixed results. A pioneering study made in the UK showed that BANs contributed to mobilizing capital that would otherwise have remained invisible and promoted a number of investments which in turn, help to free bank lending (Harrison and Mason 1996). Similarly, the study by Collewaert et al. (2007) concluded that BANs played a positive role in Flanders (Belgium), enabling businesses to leverage other sources of finance. More recently, another study drawing on the Belgium experience by Collewaert et al. (2010) underlined the role of BANs in joining investors and entrepreneurs, concluding that angel investors would not have known about $82 \%$ of the deals in which they invested had it not been for the business angel networks. This positive assessment of the role played by BANs was not however found in other studies, some concluding that BANs were not an important source of investment for most BAs (Mason and Harrison 2002) and did not contribute to the quality of deals (Mason and Harrison 1999).

The aim of our study is to contribute to a better understanding of BANs' role in developing informal venture capital markets by analysing BAs' use of the different services provided by the BANs. Additionally, we seek to test if there is a difference in the BANs services used by BA sub-groups, with these sub-groups resulting from application of age, education, investment experience and forecasting investment criteria. We also contribute to our understanding of the location aspect in start-up financing, comparing two groups (BANs of high gross regional product (GRP) regions and BANs of low GRP regions) and assessing their contribution to the BAs of these regions and indirectly to finance innovative start-ups of these two types of location. This paper contributes to the scarce empirical research in the area of BA financing and their regional and national implications.

The study is undertaken in the Portuguese context, whose characteristics are consistent with other small emergent European BA markets. It also provides a very useful field in that the BANs are developing, at the same time that there is increased interest from BAs to play a part in the burgeoning entrepreneurship story in the country. Moreover, public policy is keen to make BANs more effective, and create the right mechanisms to channel funding in the most productive ventures. We believe that the results of this study would contribute to promoting wider discussion and greater knowledge of the role of BANs and also to make rational and well-grounded policy decisions by government authorities. 
The remainder of our paper is structured as follows. In the next section, we briefly present the context this study was based on. "Methodology" describes how the sample was compiled and the methods used. The results of our analysis are presented in "Findings". "Discussion and conclusions" contains the discussion and conclusions outlined.

\section{The Portuguese context}

\section{Business structure and financial system: brief characterization}

The structure of the Portuguese economy is based on the services industry. In 2013, this sector accounted for $76.6 \%$ of gross value added (GVA) and employed $66.1 \%$ of the working population (EC 2013). SMEs are very important for Portugal's economy. Approximately $99.8 \%$ firms are SMEs, employing more than three quarters of all private sector employees. They generate $68.4 \%$ of value added in the business economy (INE 2014). Portuguese firms are specialized in low-tech manufacturing and less knowledge-intensive services. Although over the past years the Portuguese economy has made some changes in manufacturing, moving from high dependence on textiles, footwear and others to new sectors with a larger amount of technology, it has gained importance and significant growth, sectors such as the automotive and components sector, electronics, energy and pharmaceutical sector (INE 2014).

Regarding the financial system, Portugal has a culture that is geared towards bank financing. The difficulty of the Portuguese banks, from the beginning of the crisis (2008), there has been a continued decrease in loans (new business) and a tightening of other lending conditions (Bank of Portugal 2013). The interest rate spread has increased continuously since 2008, and was, on average 3 percentage points above the Eurozone average. In the case of new loans up to 1 million euros (which are intended mainly for start-ups), Portugal, along with Greece, has the highest interest rates in the Eurozone (Jevčák and Briciu 2013). This development contributed to a sharp increase in the difficulties of access to credit by the innovative start-ups. In parallel, venture capital firms in Portugal as in other countries have shifted their focus to later stages of investment where returns are higher, and it is easier to raise new funds, thereby widening the early-stage funding gap (Mason 2009; OECD 2011; Sohl 2012). Venture capital activity in Portugal since 2008 was dominated by "buyouts" and "capital growth" and "start-up" investments were respectively just 14 and $5 \%$ of total $\mathrm{VC}$ investment. Capital market is not a real solution for start-ups. Alternext, a market developed and regulated by Euronext, specifically designed for SMEs and available for up capital from 2.5 million euros, has only two companies. In this context, business angels have become an even more significant source of finance for innovative start-ups.

\section{Business angels' networks}

The European business angel network (EBAN) listed two National Associations and ten regional BANs in Portugal, and estimated that there were 562 member angels (EBAN 2012). All existing national associations and regional BANs are legally established associations and have obtained some sort of national support. The 
Portuguese Association of Business Angels (APBA) has its headquarters in Lisbon and was formally created in March 2006 with the mission of stimulating BAs and entrepreneurship activity, attracting a relevant number of BAs and supporting the development of regional and sector networks. APBA is a member of EBAN-European Business Angel Network - with which it shares experiences and best practices. APBA aims to perform a dual role as it operates both as the Federation of Business Angel Networks and as well as the Business Angel Network, but so far it has essentially played the role of BAN focusing on the financing of innovative start-ups of Greater Lisbon. APBA has a computing tool called GUST which allows entrepreneurs to submit their projects, and all the projects received are analysed and pre-assessed by the Application Management Commission of APBA and made available to all its members. Approximately half the promoters submitting projects to APBA are invited to present their projects personally to the APBA members at events held especially for that sole purpose. On their own initiative, APBA members can also initiate their process of assessing available projects and contact the entrepreneur directly with questions and proposals to explore working together. The APBA site provides the name of most members (140 BAs and 2 institutional associates) and states that it has an investment capacity of over 10 million euros. APBA has also established various protocols with universities, centres of technology and venture capitalists, and each year is involved in a variety of events promoting entrepreneurship and BA investment. Services offered by APBA include the following: (i) investment meetings/networking meetings; (ii) newsletters or information bulletins; (iii) database of contacts, (iv) online matching, (v) company presentation events and (vi) investment forums and fairs.

The second national association, the Portuguese National Federation of Business Angels (FNABA), was formally created in February 2007 by a group of regional BANs, with the mission of representing the interests of regional networks established in Portugal. FNABA intends to be a coordinating body contributing to strengthening and encouraging business angel activity in Portugal. Services offered by FNABA include the following: (i) investment meetings/networking meetings, (ii) newsletters or information bulletins, (iii) database of contacts, (iiii) online matching, (v) start-up presentation and (vi) investment forums and fairs.

Both APBA and FNABA worked with government authorities and CMVMPortuguese Securities Market Authority - in the preparation of a legal framework for business angels. Later, these two national associations worked with public administration to develop a tax incentive framework for business angels and to promote its public discussion. More recently, both organizations have been working with Portuguese authorities to construct and publicize the co-investment fund for business angels destined to enhance business angel activity.

APBA and FNABA also developed activities aiming for collaboration between business angels and formal venture capital, namely with InovCapital - the public VC in Portugal - and have made a great effort to discuss with Portuguese authorities the role of business angels in developing the Portuguese economy.

In Portugal, a set of 10 regional BANs covers the country. Although Portugal is not among the leading European countries in terms of number of networks (these being France, 80; the UK, 64; Spain, 54 and Germany, 41), it belongs to a second tier of countries with a significant number of business angel networks which also include Sweden, Russia, Switzerland, the Netherlands and Italy (OECD 2011). In fact, there are 
10 BANs in Portugal covering each of the regions of the mainland (with no reference to active BANs in the islands of the Azores and Madeira). The ten BANs existing in Portugal operate on regional scales, so-called regional business angel networks. APBA despite having national scope in 8 years have passed since its inception has funded only innovative start-ups of the Greater Lisbon region. Some of the Portuguese BANs manage their own website and the Angelsoft platform. Among regional BANs, we can find for example one based in the north of Portugal (Invicta Angels), with more than 50 associates and significant activity, and whose website provides detailed information regarding preferred sectors for investment, business plan models, a platform for submission of projects and organization of workshops or fairs, etc. At the other extreme, we have some BANs based in smaller inland regions, with less visible activity, which only publicize the name of the directors, contacts and address. Despite their small size, regional BANs periodically support or host decentralized events promoted by FNABA.

Services offered vary a great deal from one BAN to another. Some limit themselves to supporting activities carried out by FNABA whereas others can offer to a greater or lesser extent some of the following activities: (i) investment meetings/networking meetings, (ii) newsletters or information bulletins, (iii) database of contacts, (iv) online matching, (v) workshops, (vi) company presentation events, (vii) investment forums and fairs and (vii) training in investment readiness for SMEs.

\section{Methodology}

Empirical analysis of BA activity including the difficulty in forming samples of business angels is widely known (Benjamin and Margulis 1996). The strong desire for anonymity among these investors and the consequent lack of directories of business angels has meant researchers have typically had to rely upon samples of convenience (Mason and Harrison 2002).

Our study used two sources to gather the sample. After previous contacts with the Portuguese Association of Business Angels (APBA) and Portuguese Federation of BANs (FNABA), which has 10 associated regional BANs covering each of the regions country, in November 2012 the respective managers agreed to send a cover e-mail to investors registered with their service, containing besides the aims of the study, a link to the online questionnaire. In the 6 weeks that followed the e-mail, 59 valid responses were received and considered. In addition, we obtained another 29 responses at meetings of business angels held in six cities in the south, centre and north of Portugal during the entrepreneurship week (November 2012).

Concerning the representativeness of our sample, the difficulty of calculation is obvious, given that we have a population size that is unknown and probably unknowable (Wetzel 1983). Nevertheless, if we consider a good estimate that the number of business angels in Portugal in 2012 was 562 (EBAN 2012), as the total number of responses obtained was 88 , the representativeness of our sample could be estimated as a very satisfactory rate of $15.7 \%$.

A survey instrument was developed to collect data through closed questions and asked investors to report about the following: (a) investor characteristics: personal and experience background; (b) investment activity: number, amounts and results of 
investments made in the previous 5 years; (c) forecasted number and amounts of investments to be made within 1 year and (d) use (yes/no) of nine types of services provided by BANs: (1) help the entrepreneur/company/companies to be analysed, (2) help in finding the entrepreneur/company/companies to make the investment, (3) increase interaction with formal venture capital, (4) facilitate participation in angel syndicates, (5) facilitate participation in co-investment funds, (6) support investment readiness for investee companies (or potential investee companies), (7) due diligence support, (8) training/capacity building and (9) participation in forums, fairs and workshops held/sponsored by BANs.

The survey specified that respondents should only take into account in its answers activities relating to innovative start-ups. To this end, an innovation is the implementation of a new or significantly improved product (good or service) or process or a new marketing or organizational method in business practices, workplace organization or external relations (OECD/Eurostat 2005). In line with this definition, we felt that innovative start-up can be defined the one que proposes to implement at least one type of innovation.

A total of 88 useable responses were received and analysed using non-parametric statistical techniques.

We used chi-square test for independence to explore the relationship between two categorical variables (with two or more categories). We had in attention assumptions of the chi-square that include the following: (1) The data in the cells should be frequencies, or counts of cases rather than percentages or some other transformation of the data; (2) The levels (or categories) of the variables are mutually exclusive; (3) Each subject may contribute data to one and only one cell in the $\chi 2$; (4) The study groups must be independent and (5) The value of the cell expected should be 5 or more in at least $80 \%$ of the cells, and no cell should have an expected of less than 1 . When we had a 2 by 2 table, it is recommended que the frequency be at least 10 . When the 2 by 2 table violates this assumption, we have used Fisher's exact probability test instead.

Complementarily, we used Z-test to compare the proportions from independent groups when there are more than two groups.

\section{Findings}

The characteristics of respondents are shown in Table 1. Most Portuguese business angels are male (94\%) and about $4 / 5$ are more than 40 years. Only $10.3 \%$ of BAs do not have a high level of education. Angel investors are widely distributed geographically (52.3\% in high GRP regions and $47.7 \%$ in low GRP regions).

One third of respondents had made at least one or two investment in the last 5 years (Table 2). The most common pattern has been to make three or four investments. These investors typically invested between the $50,000 €$ and $250,000 €$ range in this period $(50.8 \%)$. The majority of the investments that the respondents made in this period were still in their portfolios. A high number of BAs did envisage making investments in the next year. However, most of these investors expected only to make one or two investment and one third expected to invest under 50,000 €.

The results obtained (Table 3 ) reveal that $75.6 \%$ of respondents have already participated in forums, fairs and workshops, which were held and or sponsored by 
Table 1 Descriptive statistics: investor characteristics

\begin{tabular}{lllr}
\hline Characteristic & & Number of respondents & Percent \\
\hline \multirow{2}{*}{ Gender } & Male & 83 & 94.3 \\
& Female & 5 & 5.7 \\
Age & Total & 88 & 100.0 \\
& $18-40$ years & 19 & 21.6 \\
& 41-50 years & 33 & 37.5 \\
& 51-60 years & 22 & 25.0 \\
& $>60$ years & 14 & 15.9 \\
Education & Total & 88 & 100.0 \\
& Not higher education $(<12$ years $)$ & 9 & 10.3 \\
& Higher education & 32 & 36.3 \\
Region & Post-graduate, master or PhD & 47 & 53.4 \\
& Total & 88 & 100.0 \\
& Higher GRP & 46 & 52.3 \\
& Low GRP & 42 & 47.7 \\
& Total & 88 & 100.0 \\
\hline
\end{tabular}

BANs. The BANs are often facilitators of cooperation between business angels (51.8\% in the case of angel syndicates) and is mainly through BANs that a considerable number of BAs contact with the formal venture capital (50\%). A significant number of angel investors received some kind of BAN support when they participated in coinvestment funds. It was through the BANs that $26.1 \%$ of BAs found start-ups that then led to investment realization. On the other hand, the services least used by BAs were "Support investment readiness for (potential) investee start-ups" and "Due diligence support", with 17.2 and $19.2 \%$ of affirmative responses, respectively.

When we divide the sample according to BAs' being situated in a region with higher gross regional product (GRP) such as Lisbon and Oporto, and low GRP (other Portuguese regions), a chi-square test for independence (with Yates continuity correction) indicated a significant association between region and use of services provided by BANs for finding start-ups to be analysed: $\chi^{2}(1 ; n=88)=4.548 ; p=0.033$, phi $=0.25$ (Table 4).

In regions of higher GRP, $63.6 \%$ of BAs had the support of BANs in finding startups to be analysed, contrasting with only $38.6 \%$ of BAs situated in regions with a low GRP. We did not find significant differences in the use of other BAN services between the BAs of regions with higher GRP and BAs of regions with low GRP.

To test the association between BA age and use of BANs services, we divided the sample into four age groups (18-40 years; $41-50$ years; $51-60$ years; $60+$ years), observing a significant association between age and three services provided by BANs: (1) "Facilitate increased interaction with VC": $\chi 2(3 ; n=84)=13.896, p=$ 0.003; Cramer's $V=0.407$; (2) "Facilitate participation in angel syndicates": $\chi 2$ (3; $n=83)=8.847 ; p=0.031$, Cramer's V=0.326 and (3) "Training/capacity building": $\chi 2$ (3; $n=88)=10.337 ; p=0.016$, Cramer's $V=0.343$ (Table 2). 
Table 2 Descriptive statistics: investment activity

\begin{tabular}{|c|c|c|c|c|c|}
\hline \multicolumn{2}{|l|}{ Characteristic } & \multirow{2}{*}{$\begin{array}{l}\text { Frequency } \\
22\end{array}$} & \multirow{2}{*}{$\begin{array}{l}\text { Percent } \\
25.0\end{array}$} & \multirow{2}{*}{$\begin{array}{l}\begin{array}{l}\text { Valid } \\
\text { percent }\end{array} \\
33.8\end{array}$} & \multirow{2}{*}{$\begin{array}{l}\begin{array}{l}\text { Cumulative } \\
\text { percent }\end{array} \\
33.8\end{array}$} \\
\hline Investment number (last 5 years) & One or two & & & & \\
\hline & Three or four & 29 & 33.0 & 44.6 & 78.4 \\
\hline & Five or more & 14 & 16.0 & 21.6 & 100.0 \\
\hline & Total & 65 & 73.9 & 100.0 & \\
\hline & Missing system & 23 & 26.1 & & \\
\hline & Total & 88 & 100.0 & & \\
\hline \multirow{6}{*}{$\begin{array}{l}\text { Investment amount } \\
\text { (last } 5 \text { years) }\end{array}$} & $<50,000 €$ & 15 & 17.0 & 23.1 & 23.1 \\
\hline & $50,000 €-250,000 €$ & 33 & 37.5 & 50.8 & 73.9 \\
\hline & $250,000 €-500,000 €$ & 17 & 19.3 & 26.1 & 100.0 \\
\hline & Total & 65 & 73.9 & 100.0 & \\
\hline & Missing system & 23 & 26.1 & & \\
\hline & Total & 88 & 100.0 & & \\
\hline \multirow[t]{5}{*}{ Outcome of investment } & Still in portfolio & 127 & 63.8 & & \\
\hline & Failed investments & 34 & 17.1 & & \\
\hline & Sale at break-even & 13 & 6.5 & & \\
\hline & Sale at financial gain & 25 & 12.6 & & \\
\hline & Total & 199 & 100 & & \\
\hline \multirow{6}{*}{$\begin{array}{l}\text { Number of investments } \\
\text { forecast (next } 12 \text { months) }\end{array}$} & One or two & 45 & 51.1 & 60.8 & 60.8 \\
\hline & Three or four & 21 & 23.9 & 28.4 & 89.2 \\
\hline & Five or more & 8 & 9.1 & 10.8 & 100.0 \\
\hline & Total & 74 & 84.1 & 100.0 & \\
\hline & Missing system & 14 & 15.9 & & \\
\hline & Total & 88 & 100.0 & & \\
\hline \multirow{6}{*}{$\begin{array}{l}\text { Amount of investment } \\
\text { forecast (next } 12 \text { months) }\end{array}$} & $<50,000 €$ & 25 & 28.4 & 33.8 & 33.8 \\
\hline & $50,000 €-250,000 €$ & 36 & 40.9 & 48.6 & 82.4 \\
\hline & $>250,000 €$ & 13 & 14.8 & 17.6 & 100.0 \\
\hline & Total & 74 & 84.1 & 100.0 & \\
\hline & Missing system & 14 & 15.9 & & \\
\hline & Total & 88 & 100.0 & & \\
\hline
\end{tabular}

We used the Z-test to compare the proportions from independent age groups to determine whether there were significant differences between them. In the case of BAN support to "Facilitate increased interaction with $\mathrm{VC}$ ", the observed results indicate there is a significant difference between groups 1 and 3 , groups 2 and 4 and groups 3 and 4 , at the 0.05 level of significance, i.e. the observed proportion for the 51-60 years group is significantly different from the observed proportion for younger and older age groups using BAN-provided services to interact with formal risk capital. The observed proportion for the 41-50 years group is significantly different from the observed proportion for the $60+$ years group. It is in the 41-50 and 51-60 age groups that BAs resort most to the facilitating role of BANs to cooperate with VCs. 
Table 3 Use of the services provided by BANs

\begin{tabular}{|c|c|c|c|c|c|}
\hline \multirow[t]{2}{*}{ Services provided by BANs } & \multirow[t]{2}{*}{ Number } & \multicolumn{2}{|l|}{ Yes } & \multicolumn{2}{|l|}{ No } \\
\hline & & Frequency & $\begin{array}{l}\text { Valid } \\
\text { percent }\end{array}$ & Frequency & $\begin{array}{l}\text { Valid } \\
\text { percent }\end{array}$ \\
\hline 1. Find start-ups to be analysed & 88 & 44 & 50.0 & 44 & 50.0 \\
\hline 2. Find start-ups that led to investment & 88 & 23 & 26.1 & 65 & 73.9 \\
\hline 3. Increase interaction with $\mathrm{VC}$ & 84 & 42 & 50.0 & 42 & 50.0 \\
\hline 4. Facilitate participation in angel syndicates & 83 & 43 & 51.8 & 40 & 48.2 \\
\hline $\begin{array}{l}\text { 5. Facilitate participation in co-investment } \\
\text { funds }\end{array}$ & 87 & 36 & 41.4 & 51 & 58.6 \\
\hline 6. Support investment readiness & 87 & 15 & 17.2 & 72 & 82.8 \\
\hline 7. Due diligence support & 88 & 17 & 19.3 & 71 & 80.7 \\
\hline 8. Training/capacity building & 88 & 25 & 28.4 & 63 & 71.6 \\
\hline 9. Forums, fairs and workshops & 86 & 65 & 75.6 & 21 & 24.4 \\
\hline
\end{tabular}

In the same way as for the use of BAN services to facilitate participation in angel syndicates, the Z-test shows that the column proportions of the 51-60 age group differ significantly from the $18-40$ and $60+$ groups at the 0.05 level of significance, with the 51-60 age group being the one that turns most to BANs to form angel syndicates.

There is also a significant difference between groups 2 and 4, and groups 3 and 4 concerning the use of BAN services related to "training / capacity building". The observed proportion for the two middle-aged groups (BAs that resort most to this type of support) are significantly different from the observed proportion for the older age group (not using this BAN service).

To test the association between BA education and use of BAN services, the sample was divided in three groups (not possessing higher education, higher education, postgraduate education). The results also show a significant association between "education" and two services provided by BANs: "Find company/companies to be analysed": (1) Fisher's Exact Test $(n=88)=7.862 ; p=0.019$, Cramer's $V=0.299$ and (2) "Facilitate participation in co-investment funds": $\chi 2(2 ; n=87)=8.173 ; p=0.017$, Cramer's $V=0.307$ (Table 2).

The results of the Z-test indicate there is a significant difference at the 0.05 level of significance between the "No Higher Education" group and the "Post-graduate Education" group regarding the service of "Find start-ups to be analysed", and also between the "No Higher Education" group and the other two groups in use of the "Facilitate participation in co-investment funds" service, i.e. the observed proportion for the group without higher education is significantly different from the observed proportion for the groups with higher levels of education that present greater use of these two services provided by BANs (Table 4).

We also tested the association between the number of investments made by BAs in the last 5 years $(1-2 ; 3-4 ; 5+)$ and use of BAN services and between the amount of investment forecast in the next 12 months $(<50000 € ; 50000 €-250,000 € ; 250000+$ $€)$ and use of BAN services (Table 5). 
Table 4 Use of BAN services according to region, age and education (chi-square test)

\begin{tabular}{|c|c|c|c|}
\hline & $\begin{array}{l}\text { Region } \\
\text { (1) Higher GRP } \\
\text { (2) Low GRP }\end{array}$ & $\begin{array}{l}\text { Age } \\
\text { (1) } 18-40 \text { years } \\
\text { (2) } 41-50 \text { years } \\
\text { (3) } 51-60 \text { years } \\
\text { (4) } 60 \text { +years }\end{array}$ & $\begin{array}{l}\text { Education } \\
\text { (1) Not higher education } \\
\text { (2) Higher education } \\
\text { (3) Post-graduate education }\end{array}$ \\
\hline $\begin{array}{l}\text { 1. Find start-ups to } \\
\text { be analysed }\end{array}$ & $\begin{array}{l}4.548 \\
0.033^{*}\end{array}$ & $\begin{array}{l}2.044 \\
0.563\end{array}$ & $\begin{array}{l}7.862^{\#} \\
0.019^{\mathrm{d}, *}\end{array}$ \\
\hline $\begin{array}{l}\text { 2. Find start-ups leading } \\
\text { to investment }\end{array}$ & $\begin{array}{l}0.000 \\
1.00\end{array}$ & $\begin{array}{l}3.564 \\
0.313\end{array}$ & $\begin{array}{l}0.878^{\#} \\
1.00\end{array}$ \\
\hline 3. Increase interaction with $\mathrm{VC}$ & $\begin{array}{l}000 \\
1.00\end{array}$ & $\begin{array}{l}13.896 \\
0.003^{\mathrm{a}, * *}\end{array}$ & $\begin{array}{l}3.191^{\#} \\
0.238\end{array}$ \\
\hline $\begin{array}{l}\text { 4. Facilitate participation in } \\
\text { angel syndicates }\end{array}$ & $\begin{array}{l}0.117 \\
0.733\end{array}$ & $\begin{array}{l}8.847 \\
0.031^{\mathrm{b}, *}\end{array}$ & $\begin{array}{l}2.931^{\#} \\
0.195\end{array}$ \\
\hline $\begin{array}{l}\text { 5. Facilitate participation in } \\
\text { co-investment funds }\end{array}$ & $\begin{array}{l}0.000 \\
1.00\end{array}$ & $\begin{array}{l}4.179 \\
0.243\end{array}$ & $\begin{array}{l}8.173 \\
0.017^{\mathrm{e}, *}\end{array}$ \\
\hline $\begin{array}{l}\text { 6. Support investment } \\
\text { readiness }\end{array}$ & $\begin{array}{l}0.511 \\
0.475\end{array}$ & $\begin{array}{l}3.676 \\
0.299\end{array}$ & $\begin{array}{l}0.578 \\
0.749\end{array}$ \\
\hline 7. Due diligence support & $\begin{array}{l}0.562 \\
0.454\end{array}$ & $\begin{array}{l}4.785 \\
0.188\end{array}$ & $\begin{array}{l}0.589 \\
0.745\end{array}$ \\
\hline 8. Training/capacity building & $\begin{array}{l}0.018 \\
0.893\end{array}$ & $\begin{array}{l}10.337 \\
0.016^{\mathrm{c}, *}\end{array}$ & $\begin{array}{l}4.029 \\
0.133\end{array}$ \\
\hline $\begin{array}{l}\text { 9. Forums, fairs and } \\
\text { workshops } \\
\text { held/sponsored } \\
\text { by BANs }\end{array}$ & $\begin{array}{l}0.760 \\
0.383\end{array}$ & $\begin{array}{l}6.943 \\
0.074\end{array}$ & $\begin{array}{l}0.927 \\
0.629\end{array}$ \\
\hline
\end{tabular}

${ }^{*} p<0.05 ;{ }^{* *} p<0.01 ;{ }^{*}$ Fisher's exact test result

${ }^{\mathrm{a}} \mathrm{Z}$-test detected a statistically significant relationship between groups $1-3$, groups $2-4$ and groups $3-4$

${ }^{\mathrm{b}} \mathrm{A}$ Z-test detected a statistically significant relationship between groups 3-1, groups 3-4

${ }^{\mathrm{c}}$ A Z-test detected a statistically significant relationship between groups 2-3 groups 2-4

${ }^{\mathrm{d}}$ A Z-test detected a statistically significant relationship between groups 1-3

${ }^{\mathrm{e}}$ A Z-test detected a statistically significant relationship between groups 1-2 and groups 1-3

A significant association was found between the number of investments made by BAs in the last 5 years and two services provided by BANs: "Find start-ups leading to the investment": (1) Fisher's Exact Test $(n=36)=13.824 ; p=0.001$, Cramer's $V=0.626$ and (2) "Facilitate participation in co-investment funds": $\chi 2(2 ; n=65)=11.474 ; p=$ 0.003 , Cramer's $V=0.420$. The results of the Z-test indicate that in both situations there is a significant difference at the 0.05 level of significance between the group of BAs that made one or two investments and the groups of BAs that made " 3 or 4 investments" and " $5+$ investments" with the latter two groups of BAs being the ones making most use of these two forms of BAN support.

A significant association was also found between BAs with greater potential for investment in the next 12 months and use of the BAN service "Facilitate participation 
Table 5 Use of BAN services according to investment made or investment forecast (chi-square test)

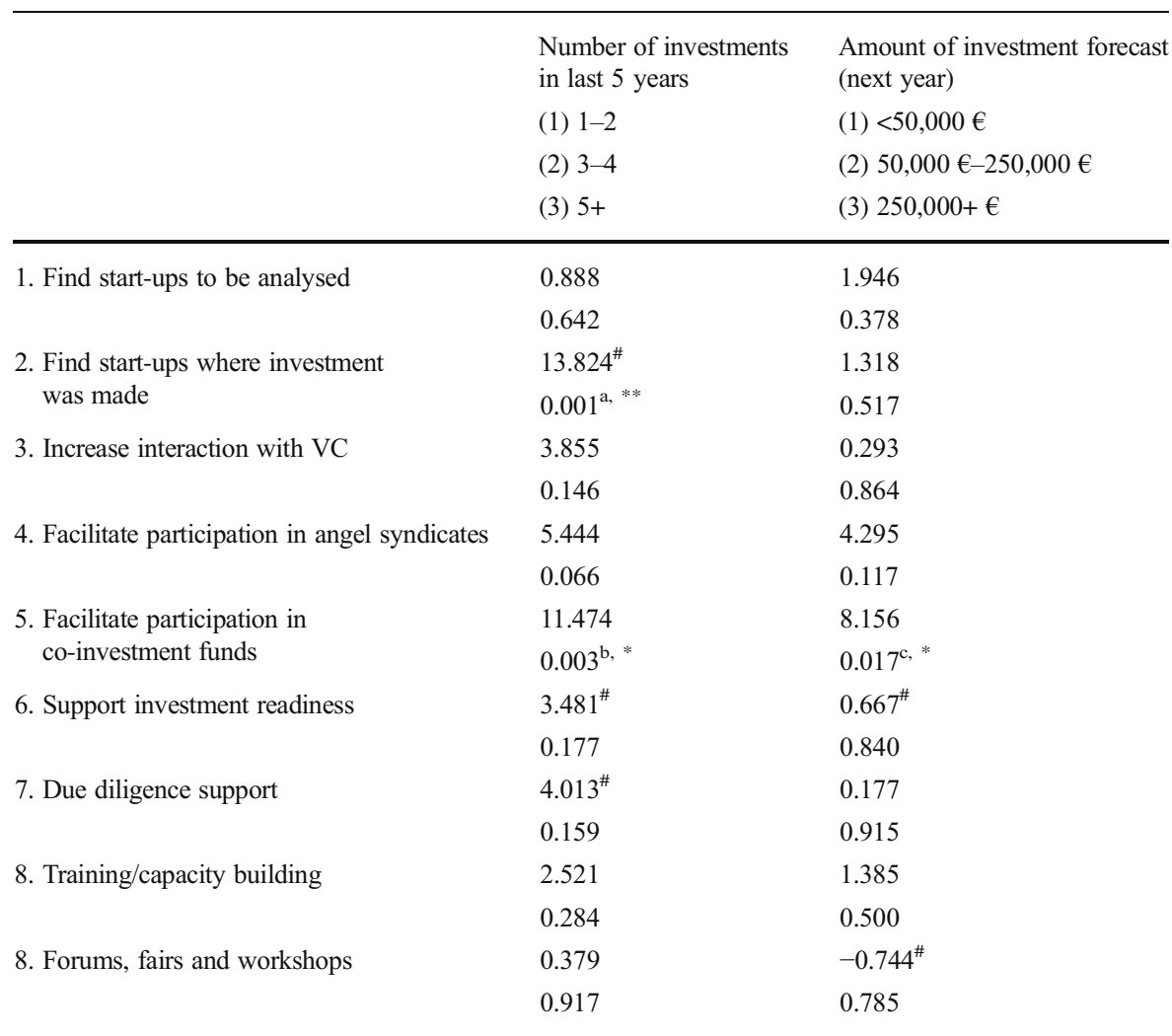

${ }^{*} p<0.05 ;{ }^{* *} p<0.01 ;{ }^{*}$ Fisher's exact test result

${ }^{\mathrm{a}} \mathrm{A}$ Z-test detected a statistically significant relationship between groups 1-2 and groups 1-3

${ }^{\mathrm{b}}$ A Z-test detected a statistically significant relationship between groups 1-2 and groups 1-3

${ }^{\mathrm{c}}$ A Z-test detected a statistically significant relationship between groups 1-2 and groups 1-3

in co-investment funds": $\chi 2(2 ; n=72)=8.156 ; p=0.017$, Cramer's $V=0.337$. Results of the Z-test indicate there is a significant difference at the 0.05 level of significance between the group of BAs forecasting investment of less than $50,000 €$ in the next 12 months and the groups of BAs whose investment estimates are between 50,000€ and $250,000 €$ or above $250,000 €$, the groups that used this type of BAN support most in the process of forming an investment vehicle entity and in co-investment fund application.

\section{Discussion and conclusions}

Our results show that BAs frequently participate in forums, fairs and workshops which were held and/or sponsored by BANs and that it is through BANs that a significant part of the BAs $(26.1 \%)$ find innovative start-ups in which to invest. Our conclusion is in line with a study previously carried out in Belgium, which showed the importance of 
BANs in joining angel investors and entrepreneurs (Collewaert et al. 2010). Our study reveals that BAs are scattered among the various regions of the country, and that it can be a real alternative to the financing of innovative start-ups, even in disadvantaged regions. It is therefore crucial to promote regional BANs so that a real impact on regional growth through enhanced start-up funding can take place.

We found that it is essentially BAs in the most developed regions and with a higher level of education (higher or post-graduate education) that used BAN services to find start-ups to be analysed. A possible justification for this regional difference could be the fact that BANs situated in the most developed regions are organizations with more sophisticated support for capturing/providing new projects (e.g. digital platforms) and consequently make a greater quantity and diversity of companies available to BAs. In addition, more developed regions are also more densely populated with greater BA anonymity, leading entrepreneurs to see BANs as a useful support to seek funding. In less developed and consequently less densely populated regions (far from major centres), entrepreneurs may approach BAs more easily by alternative means (e.g. direct contact). It is also possible that BAs with higher levels of education find it easier and are more receptive to and familiar with using BANs' digital platforms to seek target innovative start-ups.

Our results suggest that BAs in the 41-50 and 51-60 age groups made greater use of BAN support to interact with formal risk capital and to cooperate with other BAs through angel syndicates. These results may be expected in that BAs aged fewer than 40 (due to less experience) or over 60 (due to greater age) may not yet consider or already be less receptive to considering these types of cooperation. It was also found that BAs in the youngest and oldest age groups made least use of BANs for "Training / capacity building". If this seems understandable in the 60+ age group, in the youngest age group the result can be considered surprising since these BAs in principle, due to their limited experience, could benefit most from this type of support. The results also clearly indicate that BAs with higher levels of education (graduates or post-graduates), BAs more active in terms of the number of investments in the last 5 years (three or more investments made) and forecasting higher investment in the next 12 months (over $50,000 €)$ are the groups resorting most to BANs to support their participation in the coinvestment fund. Higher education, significant experience as an angel investor and the perspective of making significant investments in the near future are factors confirming the potential associated with participation in a co-investment fund and its importance for making future investments.

\section{Implications for policymakers}

Our results suggest that (1) BANs performed their role as a channel of communication between investors and entrepreneurs in order to minimize the cost of innovative startups search for capital; (2) BANs played an important role in dissemination and in supporting BA participation in angel syndicates and in the co-investment fund across different regions and (3) there was high BA adhesion to the various types of events provided by BANs. Integrated analysis of these aspects and that BANs may have also a determinant role in increasing awareness of angel investing leads us to conclude that it makes sense for the government policy support to BANs (preferably based on a regional model) when the informal venture capital market is developing and continue 
to help BA organizations until they are consolidated. This public effort concentrated on the promotion of the capital supply to innovative start-ups shows positive results in Portuguese context.

\section{Limitations and future research}

For the empirical work, the study used a European country with a developing informal venture capital market, but it was carried out at a time when its economy is in deep crisis and this may have influenced the results and consequently limits the potential for extrapolation to other European countries at a different stage of the economic cycle. This is a specific limitation that we would like to underline, while others are in common with the scant extant research on angel investment, such as the methodology used for data collection and the sample size, which necessarily have implications in terms of confidence in the results.

We suggest further exploration and more extensive research using both larger samples and samples obtained from other European countries with developing informal venture capital. Multilevel approach can be a methodology in future studies (with a micro e macro analysis) in order to find complementary and relevant results. Our work can be deepened with a complementary vision obtained by research involving interviews with responsible for innovative start-ups and heads of BANs.

Although it is acknowledged that obtaining BA data is difficult, resulting in a paucity of empirical research in this area, we strongly suggest future researchers to explore further the impact of BA presence for local entrepreneurship promotion and regional growth.

Acknowledgments The authors gratefully acknowledge three anonymous referees for their comments and suggestions made.

This paper was funded by FCT-Fundação para a Ciência a Tecnologia (The Portuguese Science Foundation) through project PTDC/EGE-ECO/112499/2009.

\section{References}

Bank of Portugal. (2013). Relatório do Conselho de Administração - A Economia Portuguesa em 2012. Lisbon: Bank of Portugal.

Benjamin, G. A., \& Margulis, J. (1996). Finding your wings: how to locate private investors to fund your venture. New York: John Wiley.

Collewaert, V., Manigart, S., \& Aernoudt, R. (2007). An assessment of government funding of business angel networks: a regional study'. Gent, Belgium: Working Paper, University of Gent.

Collewaert, V., Manigart, S., \& Aernoudt, A. (2010). Assessment of government funding of business angel networks in Flanders. Regional Studies, 44(1), 119-130.

EBAN. (2008a). European directory of business angel networks in Europe 2008. Brussels: EBAN.

EBAN. (2008b). Statistics compendium (version 3, 17 July 2008). Brussels: European Business Angels Networks.

EBAN. (2012). European angel investment overview 2012. Brussels: EBAN.

EC. (2013). Enterprise and industry PORTUGAL 2013 SBA Fact. Bruxelles: EC.

European Commission. (2003). Benchmarking business angels, BEST report No.1. Brussels: European Communities. Pot OECD 2011.

Harrison, R. T., \& Mason, C. M. (1996). Developing the informal venture capital market: a review of DTI's Informal Investment Demonstration Projects'. Regional Studies, 30, 765-772. 
INE (2014), Empresas em Portugal 2012, http://www.ine.pt/xportal/xmain?xpid=INE\&xpgid=ine publicacoes\&PUBLICACOESpub_boui=210758098\&PUBLICACOESmodo=2.

Jevčák A. and Briciu L. (2013). Drivers of diverging financing conditions across member states in Quarterly Report on the Euro Area, Volume 12, $\mathrm{N}^{\circ} 1$.

Kortum, S., \& Lerner, J. (2000). Assessing the contribution of venture capital to innovation. RAND Journal of Economics, 31(4), 674-692.

Mason, C. M., \& Harrison, R. T. (1999). Public policy and the development of the informal venture capital market: UK experience and lessons for Europe. In K. Cowling (Ed.), Industrial policy in Europe (pp. 199-223). London: Routledge.

Mason, C. M., \& Harrison, R. T. (2002). Barriers to investment in the informal venture capital sector. Entrepreneurship and Regional Development, 14(3), 271-87.

Mason, C. M. (2009). Public policy support for the informal venture capital market in Europe: a critical review. International Small Business Journal, 27(5), 536-556.

OECD/Eurostat. (2005). Oslo manual: guidelines for collecting and interpreting innovation data. In The measurement of scientific and technological activities (3rd ed.). Paris: OECD Publishing.

OECD. (2011). Financing high-growth firms: the role of angel investors. Paris: OECD publishing.

Popov, A., \& Roosenboom, P. (2012). Venture capital and patented innovation: evidence from Europe. Economic Policy, 27, 447-482.

Samila, S., \& Sorenson, O. (2011). Venture capital, entrepreneurship, and economic growth. Review of Economic Statistics, 93, 338-49.

Sohl, J. (2007). The organization of the informal venture capital market. In H. Landström (Ed.), Handbook of research on venture capital (pp. 347-368). UK: Edward Elgar.

Sohl, J. (2012). The changing nature of the angel market. In H. Landström \& C. Mason (Eds.), The handbook of research on venture capital: volume II (pp. 17-41). Cheltenham: Edward Elgar.

Wetzel, W. E., Jr. (1983). Angels and informal risk capital. Sloan Management Review, 24(4), 23-34.

Wetzel, W. E., Jr. (1987). The informal risk capital market: aspects of scale and efficiency. Journal of Business Venturing, 2, 299-313. 